6 - ORIGINAL ARTICLE

MODELS, BIOLOGICAL

\title{
Preconditioning with L-alanyl-glutamine upon cerebral edema and hypocampus red neurons counting in rats subjected to brain ischemia /reperfusion injury ${ }^{1}$
}

\author{
Paulo Roberto Cavalcante de Vasconcelos ${ }^{\mathrm{I}}$, André Brito Bastos Guimarães ${ }^{\mathrm{II}}$, Marcio Wilker Soares Campelo ${ }^{\mathrm{III}}$, Paulo Roberto \\ Leitão de Vasconcelos ${ }^{\mathrm{IV}}$, Sergio Botelho Guimaraes ${ }^{\mathrm{V}}$
}

DOI: http://dx.doi.org/10.1590/S0102-865020150030000006

${ }^{\mathrm{I}}$ Fellow PhD degree, Postgraduate Program in Surgery, Department of Surgery, Federal University of Ceara (UFC), Fortaleza-CE, Brazil. Conception and design of the study, technical procedures, acquisition and interpretation of data.

IFellow Master degree, Postgraduate Program in Surgery, Department of Surgery, UFC, Fortaleza-CE, Brazil. Technical procedures, acquisition of data.

IIIFellow PhD degree, Postgraduate Program in Surgery, Department of Surgery, UFC, Fortaleza-CE Brazil. Manuscript preparation, statistical analysis.

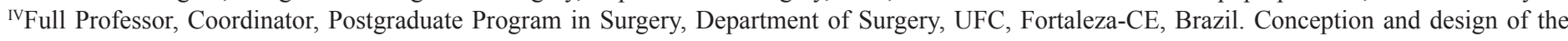
study, interpretation of data, critical revision.

${ }^{\mathrm{v}} \mathrm{PhD}$, Head, Associate Professor, Department of Surgery, Experimental Surgical Research Laboratory (LABCEX), UFC, Fortaleza-CE, Brazil. Conception, design, intellectual and scientific content of the study, critical revision, final approval.

\section{ABSTRACT}

PURPOSE: To evaluate the effects of the dipeptide L-alanyl-glutamine (L-Ala-Gln) as a preconditioning agent to potentially promote reduction in the intensity of lesion or induction of resilience in rats subjected to global cerebral ischemia/reperfusion (I/R) injury.

METHODS: Thirty-six male Wistar rats weighing 280-300g were randomly assigned to six groups $(\mathrm{n}=6)$. Groups Sham $1 \mathrm{~h}$ and $24 \mathrm{~h}$ were treated with saline and spared of further interventions. The remaining groups were submitted to clamping of the common carotid arteries for 30 minutes (ischemia) and treated with saline (SS) or L-Ala-Gln. Brain reperfusion was allowed for 1or $24 \mathrm{~h}$. L-Ala-Gln was administered intravenously $(0.75 \mathrm{~g} / \mathrm{kg}) 30$ minutes before sham procedure or induction of global brain $\mathrm{I} / \mathrm{R}$ injury. Brain edema and red neuron counting were determined. Results were expressed as Mean $\pm \mathrm{SD}$ for normal results and Median \pm Percentile for non parametric data. Significance was established at $\mathrm{p}<0.05$.

RESULTS: Global I/R injury promoted an increase in brain edema at $24 \mathrm{~h}$ after reperfusion, whereas preconditioning with L-Ala-Gln induced no change in edema. On the other hand, L-Ala-Gln preconditioning decreased significantly red neurons counting both at $1 \mathrm{~h}$ and 24h post reperfusion $(\mathrm{p}<0.05)$.

CONCLUSION: There was a significant preconditioning effect with L-Ala-Gln decreasing cell death (red neurons counting) at early (1h) and late reperfusion $(24 \mathrm{~h})$ in the cerebral tissue.

Key words: Ischemia. Reperfusion Injury. Glutamine. Brain. Apoptosis. Rats. 


\section{Introduction}

Preconditioning aims to prepare the host to a future lesion either by decreasing the intensity of its response or by inducing resilience of the organism towards the biological challenge to happen ${ }^{1}$. Various experimental and clinical studies have provided evidence of the preconditioning effects of the dipeptide l-alanyl-glutamine (L-Ala-Gln). L-Ala-Gln has been used to protect the rat testis from $\mathrm{I} / \mathrm{R}$ lesion inducing a decrease in lipid peroxidation and oxidative stress ${ }^{2}$. This glutamine dipeptide has also been able to promote hepatic protection from liver normothermic I/R in the $\mathrm{rat}^{3}$. The intravenous use of $50 \mathrm{~g}$ of this dipeptide over three hours preceeding limb revascularization has attenuated muscular tissue damage and protected from oxidative stress in patients with critical ischemia of inferior members ${ }^{4}$. In the same way the intravenous use of L-Ala-Gln $(0.5 \mathrm{~g} / \mathrm{kg})$ preoperatively has reduced inflammatory acute response in children subjected to palatoplasty ${ }^{5}$.

Neuroprotection has been reported by L-Ala-Gln preconditioning. Previous infusion of L-Ala-Gln has been shown to reduce oxidative stress and brain cell nuclear degeneration in gerbils subjected to brain ischemia/reperfusion (I/R) injury ${ }^{6}$. Preconditioning with L-Ala-Gln did not change neuronal death cell area after ischemia, however it has decreased the area of brain necrosis after I/R lesion ${ }^{7}$. The objective of the present study is to verify if preconditioning by previous intravenous injection of L-Ala-Gln would result in neuroprotection in rats subjected to global brain I/R injury.

\section{Methods}

All surgical procedures and animal handlingwere conducted in accordance with the Guide for the Care and Use of Laboratory Animals from the Brazilian College of Animal Experimentation, after approval by the local ethics committee (protocol \#62/2010). The study was designed to minimize the number of animals required for the experiments. All surgical procedures and animal handling were conducted in accordance with the Brazilian Federal Law No. 11794 of October 8, 2008 (http://www.planalto.gov.br/ccivil_03/ Ato2007-2010/2008/Lei/L11794.htm).

Thirty-six male Wistar rats (Rattus norvegicus albinus) weighing 280-300g were kept under standard housing conditions with free access to water and chow, and were randomly assigned to six groups of six animals each: Sham 1h (Saline Solution (SS) with false ischemia/reperfusion [IR] 1h); Sham 24h (SS with false IR 24h); SS followed by IR 1h (SS+I/R 1h); SS followed by IR 24h (SS+I/R 24h); L-Ala-Gln followed by IR $1 \mathrm{~h}$ (L-Ala-Gln+I/R 1h) and L-Ala-Gln followed by IR 24h (L-Ala-Gln+I/R 24h).

\section{Anesthesia}

Rats were anesthetized by an intramuscular injection of xylazine $(10 \mathrm{mg} / \mathrm{Kg})+$ ketamine $(90 \mathrm{mg} / \mathrm{Kg})$ solution. The rectal temperature was also monitored with a digital thermometer and maintained at $35-37^{\circ} \mathrm{C}$.

\section{Drug}

L-Ala-Gln is a highly stable dipeptide and when infused intravenously is promptly hydrolyzed to L-glutamine and alanine . $^{8}$ Thirty minutes before induction of ischemia, L-Ala-Gln $20 \%$ solution $(0,75 \mathrm{~g} / \mathrm{Kg})$ was administered intravenously. This dosage was based on previous experiments ${ }^{5,7}$.

\section{Induction of ischemia and reperfusion}

After anesthesia and femoral artery cannulation, experimental rats were submitted to anterior cervical incision followed by dissection of the common carotid arteries around the internal and external artery bifurcation (i.e., the clamping site), as described previously ${ }^{1}$. The rats assigned to sham groups were spared of further interventions but subsequently euthanized. The rats assigned to IR were submitted to a similar bilateral occlusion of the carotid arteries for 30 minutes, followed by release of the vascular clamp and free cerebral blood flow for 1 hour (I/R 1h) or 24h (I/R 24h) and then at the desired time after the onset of reperfusion, animals were sacrificed and sampled (brain) for hippocampal histopathology.

\section{Hippocampus histopathology}

The brain was removed from the skull and four coronal sections were made ( $2 \mathrm{~mm}$ each) and then immersion fixed in formalin for 24 hours before being transferred to $70 \%$ ethanol solution, further processed, embedded in paraffin, and cut to generate 5 - $\mu \mathrm{m}$-thick coronal sections onto slides. The slides were stained using hematoxylin and eosin. The extent of the hippocampus damage was assessed by a neuropathologist, blindly, using a light microscope (Olympus, x400). The number of pink acidophilic dead neurons (red neurons) were counted, as described by Kaku et al. ${ }^{9}$ Neuronal damage in the $\mathrm{Ca} 1, \mathrm{Ca} 2 / \mathrm{Ca} 3$ areas of the hippocampus was expressed as the percentage of dead cells in the total $400 \mathrm{X}$ microscope-field cell population. 


\section{Measurement of brain water content}

Twenty-four hours after surgical procedures (false and brain $\mathrm{I} / \mathrm{R})$, rats were killed and brains removed as described above. The pons and olfactory bulb were removed and the brains were weighted to obtain their wet weight (ww). Thereafter brains were dried at $110^{\circ} \mathrm{C}$ for $24 \mathrm{~h}$ for determining their dry weight $(\mathrm{dw})$. Brain water content was calculated by using the following formula: (ww-dw)/ww_100.

\section{Statistical analysis}

Data were subjected to Kolmogorov-Smirnov to test for normality. Normal distributed data were submitted to unpaired $t$ test. Nonparametric data were expressed as medians and percentiles (25-75), and analyzed by Mann Whitney test. The level of statistical significance was set at 5\%. GraphPad Prism 6.01 software was used for these analyses.

\section{Results \\ Cerebral edema}

Cerebral edema increased significantly $(\mathrm{p}<0.05)$ in rats treated with SS and submitted to $24 \mathrm{~h}$ IR (Figure 1). L-Ala-Gln preconditioning had no effect upon the development of brain edema $24 \mathrm{~h}$ after global I/R injury (Figure 2).

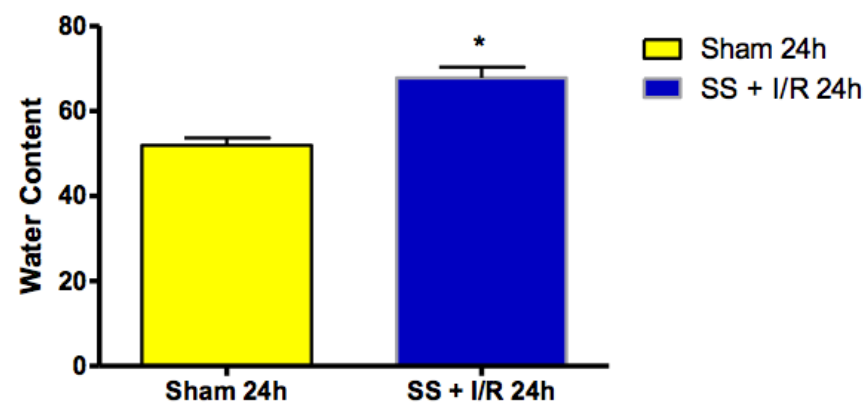

FIGURE 1 - Cerebral edema $24 \mathrm{~h}$ past sham procedure or induction of ischemia-reperfusion (IR) in rats treated with saline solution (SS) or L-Alanyl-Glutamine (L-Ala-Gln) Bars (from left to right) represent groups Sham (rats treated with SS and submitted to sham procedure, samples collected after 24h ) and L-Ala-Gln+IR 24h (rats treated with L-Ala-Gln and submitted to ischemia for 30 minutes followed by reperfusion for $24 \mathrm{~h}$ ) Significant difference was encountered when comparing groups Sham vs. L-Ala-Gln+IR 24h. Data are expressed as mean $\pm \mathrm{SD},{ }^{*} \mathrm{p}<0.05$ (unpaired $\mathrm{t}$ test).

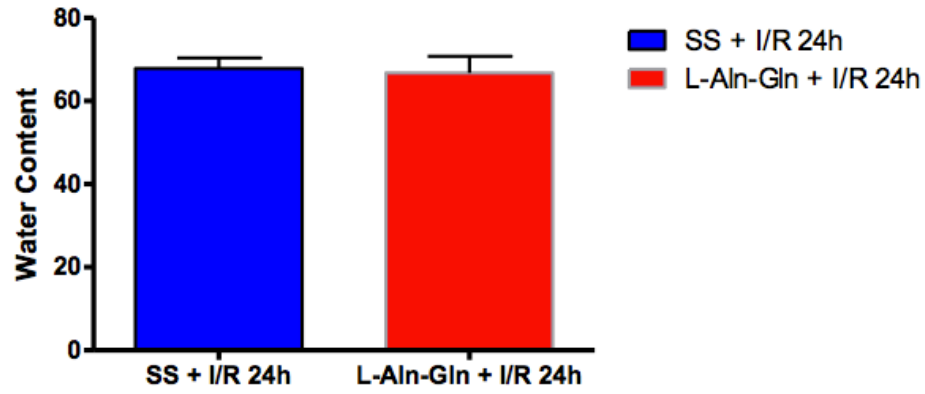

FIGURE 2 - Cerebral edema $24 \mathrm{~h}$ past induction of ischemia-reperfusion (IR) in rats treated with saline solution (SS) or L-Alanyl-Glutamine (L-AlaGln) Bars (from left to right) represent groups SS+IR 24h and L-AlaGln+IR 24h (rats treated with SS or L-Ala-Gln and submitted to ischemia for 30 minutes followed by reperfusion for $24 \mathrm{~h}$ No significant difference was encountered when comparing groups SS+IR $24 \mathrm{~h}$ vs. L-Ala-Gln+IR 24h. Data are expressed as mean $\pm \mathrm{SD}, \mathrm{p}>0.05$ (unpaired $t$ test).

\section{Red neuron counting}

Red neuron counting decreased significantly in rats submitted to IR and treated with L-Ala-Gln compared with rats submitted to IR treated with SS (Figure 3). Similar findings were seen in rats submitted to short term (1h) IR (Figure 4).

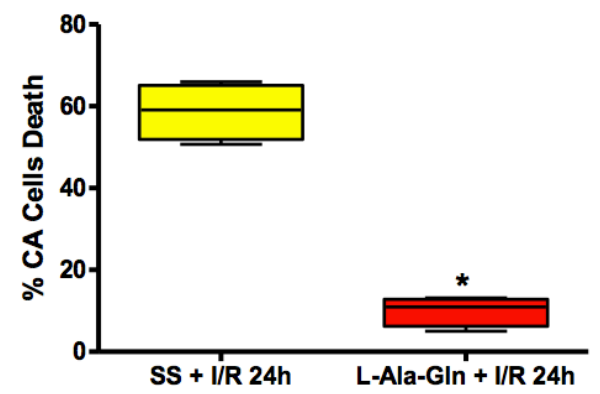

FIGURE 3 - Red neuron counting $24 \mathrm{~h}$ past induction of ischemiareperfusion (IR) in rats treated with saline solution (SS) or L-AlanylGlutamine (L-Ala-Gln) Boxes (from left to right) represent groups SS+IR 24h and L-Ala-Gln+IR 24h (rats treated with SS or L-Ala-Gln and submitted to ischemia for 30 minutes followed by reperfusion for $24 \mathrm{~h}$ ) Significant difference was encountered when comparing Groups SS+IR $24 \mathrm{~h}$ vs. L-Ala-Gln+IR 24h. Data are expressed as median \pm percentiles, $\mathrm{p}=0.029$ (Mann Whitney test). $\mathrm{CA}=$ hippocampus areas $(\mathrm{Ca} 1, \mathrm{Ca} 2 / \mathrm{Ca} 3)$.

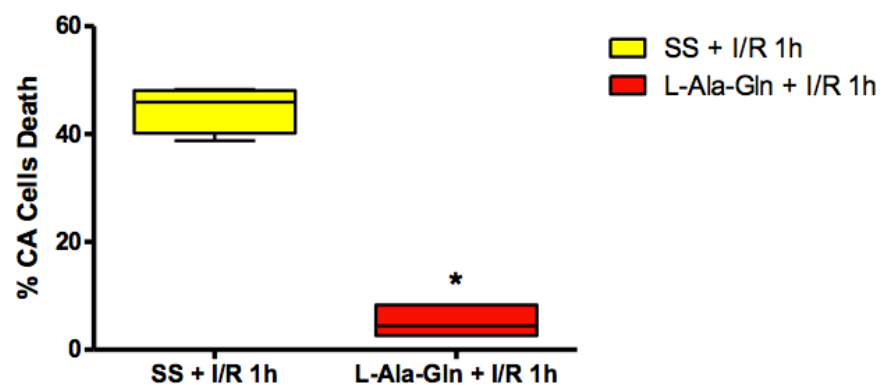

FIGURE 4 - Red neuron counting $1 \mathrm{~h}$ past induction of ischemiareperfusion (IR) in rats treated with saline solution (SS) or L-AlanylGlutamine (L-Ala-Gln) Bars (from left to right) represent groups SS+IR $1 \mathrm{~h}$ and L-Ala-Gln+IR $1 \mathrm{~h}$ (rats treated with SS or L-Ala-Gln and submitted to ischemia for 30 minutes followed by reperfusion for $1 \mathrm{~h}$ ) Significant difference was encountered when comparing Groups SS+IR $1 \mathrm{~h}$ vs. L-Ala-Gln+IR 1h. Data are expressed as median \pm percentiles, $\mathrm{p}=0.028$ (Mann Whitney test). $\mathrm{CA}=$ hippocampus areas $(\mathrm{Ca} 1, \mathrm{Ca} 2 / \mathrm{Ca} 3)$. 


\section{Discussion}

Nutraceutics have been used either as a preconditioning tool or as a treatment to change the metabolic/oxidative stress response to trauma and ischemia/reperfusion lesion ${ }^{10}$. Preconditioning with L-Ala-Gln in gerbils submitted to cerebral ischemia/reperfusion has been reported to reduce oxidative stress in the cerebral tissue ${ }^{6}$. Brain ischemic postconditioning is the induction of brief periods of ischemiareperfusion during the early stages following ischemia, and it has been shown to produce neuroprotective effects.Ischemic postconditioning resulted in significantly increased in glutamine synthetase (GS) expression compared with both the sham and ischemia-reperfusion groups, suggesting that upregulation of GS expression after ischemia constitutes a neuroprotective mechanism $^{11}$. Preconditioning with 1-ala-gln increases availability of glutamine which is trapped by glutaminase rich tissues. The previous use of intravenous 1-ala-gln has been shown to decrease brain necrosis in a rat global cerebral I/R/ injury promoting therefore neuroprotection ${ }^{7}$. Jiedu tongluo, a Chinese herbal extract complex injection has a protective effect on cerebral edema induced by the injury of focal cerebral $\operatorname{IR}^{12}$. In vitro, a novel multi-target ligand (JM-20 - 1 and $10 \mu \mathrm{M}$ ) administered during reperfusion significantly reduced cell death in hippocampal slices subjected to oxygen and glucose deprivation ${ }^{13}$. In vivo, JM-20 treatment (4 and $8 \mathrm{mg} / \mathrm{kg}$ ) significantly decreased neurological deficit scores, edema formation, total infarct volumes and histological alterations in different brain regions ${ }^{13}$. Rapamycin could improve brain edema progression after reperfusion injury through maintaining blood-brain barrier integrity and inhibiting metalloproteinase 9 and aquaporin 4 (AQP4) expression ${ }^{14}$.

In the present work preconditioning with L-Ala-Gln had no effect upon the development of brain edema $24 \mathrm{~h}$ after global I/R injury (Figures 1-2).

Previous intravenous infusion of L-Ala-Gln in gerbils subjected to brain IR has been shown to decrease degeneration of the nucleus (pyknosis) and cell death (red neurons) in the cerebral tissue ${ }^{6}$. Preconditioning with mixtures of oils containing high ratio $\omega-6 / \omega-3$ and low $\omega-9 / \omega-6$ relationship protected brain neurons against I/R injury in an experimental model of global cerebral ischemia/reperfusion by decreasing red neurons count in hippocampus area CA $3^{1}$. Fish n-3 essential fatty acids (EFA) could decrease the oxidative status and apoptotic changes in ischemic rat hippocampal formation. Dietary supplementation of n-3 EFA may be beneficial to preserve or ameliorate ischemic cerebral vascular disease ${ }^{15}$.
In the present study previous intravenous administration of L-Ala-Gln decreased cell death (red neurons counting) both at $1 \mathrm{~h}$ and $24 \mathrm{~h}$ after the induction of global brain IR in the rat (Figures 3-4). These findings give support to the neuroprotective effects of the dipeptide L-Ala-Gln as a preconditioning agent. More studies are needed to elucidate mechanisms and intracelular signalling pathways involved in the preconditioning neuroprotection.

\section{Conclusion}

Endovenous use of L-Ala-Gln at nutraceutical dose exerts a preconditioning effect by decreasing cell death (red neurons counting) at early (1h) and late reperfusion (24h) in the cerebral tissue of rats submitted to 30 minutes clamping of the common carotid arteries.

\section{References}

1. Pinheiro PM, Campelo AP, Guimarães SB, Patrocínio RM, Valença Junior JT, Vasconcelos PR. Preconditioning with oil mixes of high ratio Omega-9: Omega-6 and a low ratio Omega-6:Omega-3 in rats subjected to brain ischemia/reperfusion Acta Cir Bras. 2011;26 Suppl 1:32-7. http://dx.doi.org/10.1590/S0102-86502011000700007.

2. Leitão JP, Santos JM, Vasconcelos RC, Garcia JH, Vasconcelos PR, Guimarães SB. L-alanyl-glutamine dipeptide pretreatment attenuates ischemia-reperfusion injury in rat testis. Acta Cir Bras. 2011;26 Suppl 1:21-5. http://dx.doi.org/10.1590/S010286502011000700005.

3. Araújo Júnior RJ, Silva Júnior RG, Vasconcelos MP, Guimarães SB, Vasconcelos PR, Garcia JH. Preconditioning with L-alanylglutamine reduces hepatic ischemia-reperfusion injury in rats. Acta Cir Bras. 2011;26 Suppl 1:8-13. http://dx.doi.org/10.1590/S010286502011000700003.

4. Alves WF, Aguiar EE, Guimarães SB, da Silva Filho AR, Pinheiro PM, Soares G dos S, de Vasconcelos PR. L-alanyl-glutamine preoperative infusion in patients with critical limb ischemia subjected to distal revascularization reduces tissue damage and protects from oxidative stress. Ann Vasc Surg. 2010 May;24(4):4617. doi: 10.1016/j.avsg.2010.01.005.

5. Cunha Filho JF, Gonçalves II, Guimarães SB, Jamacaru FV, Garcia $\mathrm{JH}$, Vasconcelos PR. L-alanyl-glutamine pretreatment attenuates acute inflammatory response in children submitted to palatoplasty. Acta Cir Bras. 2011;26(Suppl 1):72-6. PMID: 21971662.

6. Pires VL, Souza JR, Guimarães SB, Silva Filho AR, Garcia JH, Vasconcelos PR. Preconditioning with L-alanyl-L-glutamine in a Mongolian gerbil model of acute cerebral ischemia/reperfusion injury. Acta Cir Bras. 2011;26(Suppl 1):14-20. http://dx.doi. org/10.1590/S0102-86502011000700004.

7. Nogueira ANC. Efeitos da 1- alanil glutamina em modelo experimental de isquemia e reperfusão em cérebro de ratos Wistar [Mestrado]. Universidade Federal do Ceará: Programa de PósGraduação em Cirurgia; 2010. Disponível em http://www.teses.ufc. br/tde_busca/arquivo.php?codArquivo=4683.

8. Albers S, Wernerman J, Stehle P, Vinnars E, Fürst P. Availability of amino acids supplied by constant intravenous infusion of synthetic dipeptides in healthy man. Clin Sci (Lond). 1989 Jun;76(6):643-8. PMID: 2736882. 
9. Kaku Y, Yonekawa Y, Tsukahara T, Ogata N, Kimura T, Taniguchi T. Alterations of a $200 \mathrm{kDa}$ neurofilament in the rat hippocampus after forebrain ischemia. J Cereb Blood Flow Metab. 1993 May;13(3):402-8. PMID: 7683024.

10. Vasconcelos PRL, Guimarães SB. Selected papers presented at the Symposium on Nutrition and Metabolism of the Brazilian Society for Development of Research in Surgery (SOBRADPEC). Acta Cir Bras. 2011;26(Suppl.1). Editorial.

11. Zhang W, Miao Y, Zhou S, Jiang J, Luo Q, Qiu Y. Neuroprotective effects of ischemic postconditioning on global brain ischemia in rats through upregulation of hippocampal glutamine synthetase. J Clin Neurosci. 2011 May;18(5):685-9. doi: 10.1016/j.jocn.2010.08.027.

12. Wu LF, Xing Y, Guan YL, Liu ZQ, Zhang WS. Protective effect of jiedu tongluo injection on cerebral edema in rats with lesion of cerebral ischemia/reperfusion. Zhongguo Zhong Yao Za Zhi. 2014 Mar;39(6):1088-92. PMID: 24956856.

13. Nuñez-Figueredo Y, Ramírez-Sánchez J, Hansel G, Simões Pires EN, Merino N, Valdes O, Delgado-Hernández R, Parra AL, OchoaRodríguez E,Verdecia-Reyes Y, Salbego C, Costa SL, Souza DO, Pardo-Andreu GL. A novel multi-target ligand (JM-20) protects mitochondrial integrity, inhibits brain excitatory amino acid release and reduces cerebral ischemia injury in vitro and in vivo. Neuropharmacology. 2014 Oct;85:517-27. doi: 10.1016/j. neuropharm.2014.06.009.

14. Guo W, Feng G, Miao Y, Liu G, Xu C. Rapamycin alleviates brain edema after focal cerebral ischemia reperfusion in rats. Immunopharmacol Immunotoxicol. 2014 Jun;36(3):211-23. doi: 10.3109/08923973.2014.913616.

15. Bas O, Songur A, Sahin O, Mollaoglu H, Ozen OA, Yaman M, Eser $\mathrm{O}$, Fidan H, Yagmurca M. The protective effect of fish n-3 fatty acids on cerebral ischemia in rat hippocampus. Neurochem Int. 2007 Feb;50(3):548-54. doi: 10.1016/j.neuint.2006.11.005.

\section{Correspondence:}

Prof. Dr. Sergio Botelho Guimaraes

Rua Barão de Aratanha, 1465

60050-071 Fortaleza-CE Brasil

Tel.: (55 85)3366-8063

sergiobotelho@terra.com.br

Received: Nov 18, 2014

Review: Jan 20, 2015

Accepted: Feb 16, 2015

Conflict of interest: none

Financial source: National Council for Scientific and Technological Development (CNPq)

${ }^{1}$ Research performed at Laboratory of Experimental Surgery (LABCEX), Department of Surgery, Federal University of Ceara (UFC), FortalezaCE, Brazil. Part of PhD degree thesis, Postgraduate Program in Surgery, UFC. Tutor: Prof. Dr. Sergio Botelho Guimaraes. 